\title{
Review Paper \\ In vitro culture of sempre-vivas species (Comanthera): a review
}

\author{
Andressa Priscila Piancó Santos Lima ${ }^{1,5}$, Alone Lima Brito ${ }^{2,3}$ \& José Raniere Ferreira de Santana ${ }^{2,4}$
}

\begin{abstract}
The term "sempre-viva" denotes plants whose structures retain their natural form and color after being cut and dried. For these reasons, they are commercially valuable for ornamental purposes. However, due to extractive overexploitation of their inflorescences, some of these species are considered endangered. The genus Comanthera includes the sempre-vivas species with greatest economic importance in Brazil. Previous studies have shown that tissue culture is a workable strategy for in vitro propagation and conservation of species of this genus. However, these studies are still incipient. Therefore, the objective of this review is to summarize the findings on the in vitro cultivation of species of the Comanthera genus, to serve as the basis for future research. The text is structured in two main topics: micropropagation and in vitro conservation.

Key words: Comanthera, in vitro culture, in vitro conservation, micropropagation, Sempre-viva.

\section{Resumo}

As sempre-vivas são plantas que mantêm o aspecto vivo de suas estruturas mesmo após serem coletadas, e por esta característica são comercializadas como ornamentais de alto valor econômico; contudo, devido à coleta extrativista de suas inflorescências algumas espécies se encontram em perigo de extinção. O gênero Comanthera compreende as sempre-vivas de maior importância econômica para o Brasil. Estudos apontam a cultura de tecidos como estratégia para a propagação e conservação in vitro de espécies deste gênero; entretanto as pesquisas publicadas ainda são incipientes. Diante disso, o objetivo desta revisão foi reunir publicações sobre o cultivo in vitro do gênero Comanthera com o intuito de fundamentar estudos futuros com suas espécies. Para tanto, esta revisão está estruturada em dois tópicos principais: micropropagação e conservação in vitro. Palavras-chave: Comanthera, cultivo in vitro, conservação in vitro, micropropagação, Sempre-viva.
\end{abstract}

\section{Introduction}

Serra do Espinhaço is a mountain range that extends from the state of Minas Gerais to the state of Bahia, Brazil, and is noted for its wide biodiversity. According to ICMBio (2018), this region is considered by the United Nations Organization (ONU) to be the seventh leading biosphere reserve in Brazil, due to the great diversity of its natural resources and flora endemism.

Among the predominant species of Serra do Espinhaço are sempre-vivas, a designation given to plants whose structures maintain a living appearance for an extended period after being cut and dried. These characteristics give these plants a high commercial value for ornamental purposes, such as decoration and production of bouquets and accessories. The sempre-vivas species most often found in commerce are those belonging to the families Xyridaceae, Cyperaceae, Gramineae and Eriocaulaceae (Giulietti et al. 1988).

Due to these potential uses, sempre-vivas plants have sometimes been overexploited as a source of subsistence or extra income by people living in or near the areas of their occurrence, causing reduction of these plants. Some species from the Eriocaulaceae family are classified as

\footnotetext{
${ }^{1}$ Universidade Estadual de Feira de Santana (UEFS), Prog. Pós-graduação em Recursos Genéticos Vegetais, Novo Horizonte, Feira de Santana, BA, Brasil. ORCID: < https://orcid.org/0000-0002-8272-3506>.

${ }^{2}$ Universidade Estadual de Feira de Santana (UEFS), Depto. Ciências Biológicas, Feira de Santana, BA, Brasil.

${ }^{3}$ ORCID: <https://orcid.org/0000-0003-3481-6481>.

${ }^{4}$ ORCID: <https://orcid.org/0000-0003-0186-6888>.

${ }^{5}$ Author for correspondence: andressapianco@gmail.com
} 
endangered, such as Comanthera mucugensis (Giul.) L.R. Parra \& Giul. and Comanthera elegans (Bong.) L.R. Parra \& Giul., or as vulnerable, such as Comanthera curralensis (Moldenke) L.R. Parra \& Giul. (CNCFlora 2012). This problem has attracted the attention of researchers about the need to apply strategies for ex situ conservation of these genetic resources. For this purpose, one of the most successful biotechnological strategies is the use of tissue culture, encompassing a set of techniques such micropropagation and in vitro conservation.

Micropropagation allows the production of a large number of plants free from pathogens (good phytosanitary quality) in a brief time period and limited space (Junghans \& Souza 2013; Coelho et al. 2016). As such, it is applied to produce seedlings for the ornamental market. The in vitro conservation technique consists of keeping cultured plants alive for as long as possible without the need for subculture. This can be achieved by alterations in the culture medium to reduce or suppress growth (Arrigoni-Blank et al. 2014), allowing maintenance of the genetic variability without the risks inherented to the field conditions.

The literature contains several studies of the micropropagation and in vitro conservation of different species of the genus Comanthera, but these are incipient, and no protocols have been established for commercial production of micropropagated plantlets, much less for the establishment of in vitro germplasm banks. In light of this context, the objective of this review is to summarize the publications on the in vitro cultivation of the genus Comanthera, to serve as a base for future studies of its species.

\section{Micropropagation of sempre-vivas species}

In vitro establishment

The pioneering studies focused on Comanthera mucugensis involved in vitro germination. Paixão-Santos et al. (2003) tested pre-germination treatments of the seeds before inoculation (chemical scarification with sulfuric acid, washing in running water, soaking and drying) and evaluated the effect of different concentrations of sucrose and gibberellic acid in culture medium containing water +8 g. $\mathrm{L}^{-1}$ of agar on in vitro establishment.

Their results indicated that the $C$. mucugensis seeds do not need to be submitted to chemical scarification and drying, and that soaking is favorable to germination. However, none of the treatments led to germination higher than approximately $55 \%$. The experiments also revealed that sulfuric acid is toxic to the seeds and that sucrose in the culture medium inhibits germination.

The low germination rates attained with all the treatments indicated the need to test new treatments for possible increase of the germination rate. In this respect, Silva et al. (2005a) obtained germination of $85.5 \%$ using seeds previously soaked in water sown in medium containing water + agar, at concentration of $7 \mathrm{~g} . \mathrm{L}^{-1}$, revealing that the seeds of the species do not have dormancy. The authors also assessed the influence of luminosity (presence or absence of light) and concluded that germination only occurs in the presence of light, indicating that the species is photoblastic positive.

Both Paixão-Santos et al. (2003) and Silva et al. (2005a) used a culture medium containing water and agar for germination, without nutrients and carbohydrates. This practice makes it necessary to transplant the recently germinated plants to a growth medium.

In this sense, Silva et al. (2005b) investigated the effect of five concentrations of sucrose (5, $10,15,20$ and 30 g. $\mathrm{L}^{-1}$ ) added to MS medium (Murashige \& Skoog 1962) with half the normal saline concentration (MS 1/2) on the in vitro growth of $C$. mucugensis plants. The results indicated that the use of $15 \mathrm{~g} . \mathrm{L}^{-1}$ of sucrose is efficient for in vitro growth of the species. The authors suggested that new studies must be conducted to optimize the establishment step.

Paixão-Santos et al. (2006) tested different concentrations of MS salts (complete, $2 / 3,1 / 2,1 / 3$ and $1 / 4$ ) on the initial growth of plants recently germinated in vitro. The results indicated that MS $1 / 2$ medium tended to provide the best results.

The studies described above indicated that the germination and initial growth of C. mucugensis in vitro should be carried out in different culture media, which would increase the production costs and risks of contamination of the plant material during transfer. However, a later study with this species demonstrated that the in vitro establishment can be accomplished from seeds germinated in MS $1 / 2$ medium supplemented with 15 g.L. - $^{-1}$ of sucrose, and the plants can be maintained in the same medium during in vitro growth (Lima-Brito et al. 2011a).

Besides C. mucugensis, studies on the in vitro establishment of other species of the genus Comanthera have also been reported. Pêgo et al. (2013) tested different concentrations $(0,25,50$, 
75 and $100 \%$ ) of woody plant medium - WPM (Lloyd \& McCown 1980) supplemented with 15 g. $\mathrm{L}^{-1}$ of sucrose for the germination of Comanthera elegantula (Ruhland) L.R. Parra \& Giul. seeds. They concluded that the germination rate wasn't influenced by the saline concentrations, and attained rates higher than $80 \%$ in all the treatments.

The authors also evaluated the effect of different culture media (WPM and MS) and saline concentrations (50 and 100\%), supplemented with $15 \mathrm{~g} . \mathrm{L}^{-1}$ of sucrose, on the in vitro establishment of plantlets. Then different concentrations of sucrose $\left(0,5,10,15,20,25\right.$ and 30 g.L. $\left.\mathrm{L}^{-1}\right)$ were used to assess the plants' development. The best result for in vitro establishment and development was obtained with WPM $100 \%$ plus 17 g. $\mathrm{L}^{-1}$ of sucrose.

The same methods for in vitro germination, establishment and development of C. elegantula were later applied by Pêgo et al. (2014) to Comanthera elegans. The best germination rate was near $70 \%$, and WPM $100 \%$ plus 17 g.L L $^{-1}$ of sucrose was the best treatment for in vitro establishment of the species.

A study for in vitro establishment of Comanthera paepalophylla (Silveira) L.R.Parra \& Giul. subsp. paepalophylla was carried out by Pêgo et al. (2015), in which the authors evaluated the germination rate of seeds cultivated on medium containing only water and agar, or on WPM, and found rates of 70.9 and $60.5 \%$, respectively, after growth for 30 days. In turn, to analyze the in vitro development, the authors used plantlets with height of $1 \mathrm{~cm}$ and tested the media MS and WPM with 50 and $100 \%$ salt concentrations, plus 15 g. $\mathrm{L}^{-1}$ of sucrose and 8 g.L. $\mathrm{L}^{-1}$ of agar, and concluded that the WPM $100 \%$ was better for plant development. That work is a pioneer regarding in vitro culture of C. paepalophylla, and its results serve as base for future studies of micropropagation and/or conservation of this sempre-viva plant.

WPM was also used by Moreira (2015) for in vitro establishment of Comanthera bisulcata (Körn.) L.R.Parra \& Giul, supplemented with 15 g. $\mathrm{L}^{-1}$ of sucrose. The author tested different immersion periods $(1,5,10,15$ and 20 minutes) of the seeds in sodium hypochlorite (1\%) on the in vitro germination and obtained the best result with 5 minutes (54\% germination rate) after in vitro culture for 30 days. In that study, the author also evaluated the influence of different $\mathrm{pH}$ values (4.4, 5.0, 5.4 and 5.8), but did not find any significant differences in the in vitro germination rate, with average of $70 \%$. Finally, Moreira (2015) analyzed the influence of silver nitrate $\left(\mathrm{AgNO}_{3}\right)$ on the control of senescence and of polyvinylpyrrolidone (PVP) on oxidation control, attaining positive results in both experiments, where the best responses were obtained with $0.2 \mu \mathrm{M}$ of $\mathrm{AgNO}_{3}$ and $400 \mathrm{mg} \cdot \mathrm{L}^{-1}$ of PVP.

For Comanthera curralensis, Albuquerque et al. (2016) evaluated the effect of different salt concentrations in MS medium (50 and 100\%) combined with 15 or 30 g.L. $\mathrm{L}^{-1}$ of sucrose on in vitro establishment. The best germination rate was $62.75 \%$, achieved with MS $1 / 2$ medium and 15 g.L. - $^{-1}$, similar to the effects observed for C. mucugensis.

\section{In vitro multiplication}

The first published study of the in vitro multiplication of Comanthera mucugensis was carried out by Paixão-Santos et al. (2008), who tested different concentrations of 6-benzylaminopurine $\operatorname{BAP}(0.0,0.89,1.78,3.55,7.14,14.21$ and 28.42 $\mu \mathrm{M})$ and explant types (entire plant and nodal segments) obtained from plants established in vitro with 60 days of culture. As a morphogenic response, the authors only observed callogenesis, with percentages of 52.50 and $49.96 \%$ for nodal segments at the concentrations of 1.78 and 3.55 $\mu \mathrm{M}$, respectively (Tab. 1). At these concentrations, the entire plant explants produced the best results for the same parameter, 71.25 and $68.75 \%$ (Tab. 1). Although the authors obtained a high rate of callus formation, they did not investigate this aspect regarding differentiation of shoots.

Later, Lima-Brito et al. (2011a) evaluated the in vitro morphogenesis of the same species with the use of the cytokinin BAP $(0.00,2.22$ and 4.44 $\mu \mathrm{M})$ in combination with the auxin naphthalene acetic acid - NAA $(0.00,1.34$ and $2.68 \mu \mathrm{M})$, and different explant types (stem, leaf and root), obtained from in vitro-germinated plants with 180 days of culture. They found that the root explants were not responsive and the leaf explants were unable to regenerate shoots, but did form calli in small percentages (12.35 and 19.73\%) when treated with $4.44 \mu \mathrm{M}$ BAP and $2.68 \mu \mathrm{M}$ NAA, respectively (Tab. 1).

However, unlike reported by Paixão-Santos et al. (2008), the authors observed regeneration of shoots in the stem explants by direct organogenesis on MS $1 / 2$ medium without growth regulator, and by indirect organogenesis on medium containing BAP. In the direct case, the shoot regeneration rate was $58.75 \%$, with 22 shoots per explant, while in the indirect case, the regeneration rates were 32.18 
Table 1 - Studies on the in vitro morphogenesis of sempre-vivas species.

\begin{tabular}{|c|c|c|c|c|c|c|}
\hline Reference & $\begin{array}{c}\text { Type of } \\
\text { morphogenesis }\end{array}$ & Explant & $\begin{array}{l}\text { Growth } \\
\text { regulator } \\
(\mu \mathrm{M})\end{array}$ & RE\%* & $\mathrm{NSE}^{* *}$ & Species \\
\hline \multirow[t]{4}{*}{ Paixão-Santos et al. (2008) } & \multirow[t]{4}{*}{ Callogenesis } & \multirow[t]{2}{*}{ Stem } & 1.78 BAP & 52.50 & 0 & \multirow{2}{*}{$\begin{array}{l}\text { Comanthera } \\
\text { mucugensis }\end{array}$} \\
\hline & & & 3.55 BAP & 49.96 & 0 & \\
\hline & & \multirow[t]{2}{*}{ Plant } & $1.78 \mathrm{BAP}$ & 71.25 & 0 & \multirow{2}{*}{$\begin{array}{l}\text { Comanthera } \\
\text { mucugensis }\end{array}$} \\
\hline & & & $3.55 \mathrm{BAP}$ & 68.75 & 0 & \\
\hline \multirow[t]{5}{*}{ Lima-Brito et al. (2011a) } & \multirow[t]{2}{*}{ Callogenesis } & \multirow[t]{2}{*}{ Leaf } & $2.68 \mathrm{NAA}$ & 19.73 & 0 & \multirow{2}{*}{$\begin{array}{l}\text { Comanthera } \\
\text { mucugensis }\end{array}$} \\
\hline & & & 4.44 BAP & 12.35 & 0 & \\
\hline & $\begin{array}{c}\text { Direct } \\
\text { organogenesis }\end{array}$ & Stem & No regulator & 58.75 & 22 & $\begin{array}{l}\text { Comanthera } \\
\text { mucugensis }\end{array}$ \\
\hline & \multirow{2}{*}{$\begin{array}{c}\text { Indirect } \\
\text { organogenesis }\end{array}$} & \multirow[t]{2}{*}{ Stem } & $2.22 \mathrm{BAP}$ & 32.18 & 28 & \multirow{2}{*}{$\begin{array}{l}\text { Comanthera } \\
\text { mucugensis }\end{array}$} \\
\hline & & & 4.44 BAP & 47.05 & 32 & \\
\hline Albuquerque (2013) & $\begin{array}{c}\text { Indirect } \\
\text { organogenesis }\end{array}$ & Leaf & $0.88 \mathrm{BAP}$ & Not evaluated & 22.83 & $\begin{array}{l}\text { Comanthera } \\
\text { mucugensis }\end{array}$ \\
\hline Gurgel (2017) & $\begin{array}{c}\text { Direct } \\
\text { organogenesis }\end{array}$ & Leaf & No regulator & 11 & 0.53 & $\begin{array}{l}\text { Comanthera } \\
\text { mucugensis }\end{array}$ \\
\hline \multirow[t]{3}{*}{ Albuquerque (2013) } & Callogenesis & Leaf & $1.34 \mathrm{NAA}$ & - & 0 & $\begin{array}{c}\text { Comanthera } \\
\text { curralensis }\end{array}$ \\
\hline & $\begin{array}{c}\text { Direct } \\
\text { organogenesis }\end{array}$ & Stem & No regulator & - & 42 & $\begin{array}{c}\text { Comanthera } \\
\text { curralensis }\end{array}$ \\
\hline & $\begin{array}{c}\text { Indirect } \\
\text { organogenesis }\end{array}$ & Stem & $0.22 \mathrm{BAP}$ & - & 7.5 & $\begin{array}{c}\text { Comanthera } \\
\text { curralensis }\end{array}$ \\
\hline \multirow[t]{2}{*}{ Pêgo et al. (2013) } & Callogenesis & Plant & $2.68 \mathrm{NAA}$ & More than 80 & 0 & $\begin{array}{c}\text { Comanthera } \\
\text { elegantula }\end{array}$ \\
\hline & $\begin{array}{c}\text { Indirect } \\
\text { organogenesis }\end{array}$ & Plant & $4.54 \mathrm{TDZ}$ & Not evaluated & More than 5 & $\begin{array}{c}\text { Comanthera } \\
\text { elegantula }\end{array}$ \\
\hline \multirow[t]{2}{*}{ Pêgo et al. (2014) } & Callogenesis & Plant & $2.68 \mathrm{NAA}$ & More than 80 & 0 & $\begin{array}{c}\text { Comanthera } \\
\text { elegans }\end{array}$ \\
\hline & $\begin{array}{c}\text { Indirect } \\
\text { organogenesis }\end{array}$ & Plant & $\begin{array}{c}2.68 \mathrm{NAA}+ \\
2.27 \mathrm{TDZ}\end{array}$ & Not evaluated & More than 25 & $\begin{array}{c}\text { Comanthera } \\
\text { elegans }\end{array}$ \\
\hline Moreira (2015) & $\begin{array}{c}\text { Indirect } \\
\text { organogenesis }\end{array}$ & Plant & $\begin{array}{l}2.68 \mathrm{NAA}+ \\
2.27 \mathrm{TDZ}\end{array}$ & 50 & Not evaluated & $\begin{array}{c}\text { Comanthera } \\
\text { bisulcata }\end{array}$ \\
\hline
\end{tabular}

* = Percentage of responsive explants; $* *=$ Number of shoots/explant.

and $47.05 \%$ at concentrations of 2.22 and $4.44 \mu \mathrm{M}$, respectively, with averages of 28 and 32 shoots per explant (Tab. 1).

In both studies, calli appeared 15 days after inoculation. The results confirmed the advance achieved by Lima-Brito et al. (2011a) regarding production of plants and showed that in vitro multiplication of the species in question is feasible.

With relation to the use of leaf explants of $C$. mucugensis, Albuquerque (2013) tested the effect of different BAP concentrations $(0.00,0.22,0.44$ and $0.88 \mu \mathrm{M})$ on the induction of indirect organogenesis 
and found the concentration of $0.88 \mu \mathrm{M}$ to be most efficient, inducing an average of 22.83 shoots per explant. However, the author suggested that higher concentrations should be tested.

Gurgel (2017) also assessed the morphogenic capacity of leaf explants, as well as stem explants of $C$. mucugensis. She tested the influence of different NAA concentrations $(0,4.9$ and $9.8 \mu \mathrm{M})$ added to MS $1 / 2$ medium containing 2 g. $\mathrm{L}^{-1}$ of activated charcoal and $4.4 \mu \mathrm{M}$ BAP. For the leaf explants, there was shoot regeneration only in the medium free of the growth regulator, with $11 \%$ responsive explants and 0.53 shoot per explant. On the contrary, for the stem explants, morphogenesis occurred at all concentrations, but there were no significant differences between them, indicating that the medium without NAA can be used for shoot multiplication via indirect organogenesis, with $60 \%$ responsive explants and 4.72 shoots per explant. Therefore, new tests can be conducted to investigate the morphogenic capacity of the leaf explants, which could enhance multiplication rates. Also, new treatments can be applied to increase shoot regeneration from stem explants. Finally, somatic embryogenesis can be tested to obtain microplants of this species.

In vitro multiplication of the sempre-viva Comanthera curralensis was carried out by Albuquerque (2013), evaluating the effect of different NAA concentrations $(0.00,1.34$ and $2.68 \mu \mathrm{M})$ and BAP $(0.00,0.22,0.44,0.88,1.76$ and $3.52 \mu \mathrm{M})$ in leaf and stem explants. The author reported different morphogenic responses, such as callogenesis and direct and indirect organogenesis, and also observed high oxidation rates from both explant types $(90.7 \%$ for stem and $79.2 \%$ for leaf explants). The best response for direct organogenesis was achieved with the stem explants in medium free of growth regulator, producing 42 shoots per explant, while for indirect organogenesis, the use of $0.22 \mu \mathrm{M}$ BAP induced an average of 7.5 shoots per explants. Finally, regarding callogenesis, the best result was obtained using the leaf explants with $1.34 \mu \mathrm{M}$ NAA.

Pêgo et al. (2013), in the study with Comanthera eleganta, also tested the effect of different combinations of the growth regulators thidiazuron - TDZ $(0.0,0.5,1.0,2.0$ or 4.0 mg. $\left.\mathrm{L}^{-1}\right)$ and NAA $\left(0.0,0.5\right.$ or $\left.1.0 \mathrm{mg} . \mathrm{L}^{-1}\right)$ on the entire plantlet. The morphogenic response obtained was the formation of calli with 2.68 $\mu \mathrm{M}$ NAA, and regeneration of shoots by indirect organogenesis produced the best average results in the combination of $4.54 \mu \mathrm{M}$ TDZ with $2.68 \mu \mathrm{M}$ NAA, or the use alone of $4.54 \mu \mathrm{M}$ TDZ.

The same combinations and concentrations of growth regulators used by Pêgo et al. (2013) were again tested by Pêgo et al. (2014), with Comanthera elegans using the entire plant. The authors also observed the formation of calli and indirect shoots. Callogenesis was obtained in response to 2.68 or $5.36 \mu \mathrm{M}$ NAA or in the combinations of 2.68 with $2.27,5.36$ with 4.54 and 5.36 with 18 NAA and TDZ, respectively. On the other hand, the formation of shoots occurred in combinations of $2.68 \mu \mathrm{M}$ NAA with $2.27 \mathrm{TDZ}$, and 5.36 $\mu \mathrm{M}$ NAA with 4.54 TDZ.

In vitro multiplication using entire plantlets was described by Moreira (2015), evaluating the influence of different cytokinins (BAP, TDZ and kinetin - KIN) associated with $2.68 \mu \mathrm{M}$ NAA. The author reported the occurrence of indirect organogenesis as a morphogenic response and concluded that the addition of $2.68 \mu \mathrm{M}$ NAA + $2.27 \mu \mathrm{M} \mathrm{TDZ}$ was best for shoot induction, with a regeneration rate of $50 \%$. This combination of growth regulators was then applied to compare two culture systems, liquid and semi-solid media. The best responses for relative growth rate and average plant weight were obtained in the liquid system. The author concluded that the liquid medium should be tested with other sempre-viva species, in order to enhance the responses of in vitro culitivation, besides reducing the cost with the gelling agent.

In light of the results obtained with the Comanthera species studied by Pêgo et al. (2013, 2014) and Moreira (2015), different explants should be tested in the multiplication step, so as investigate all parts of in vitro-germinated plants, to broaden the possibilities for their use. In addition, the use of culture medium without growth regulator for shoot induction should be analyzed as a strategy to reduce costs, along with regeneration by direct organogenesis with the aim of preserving genetic fidelity.

\section{In vitro rooting}

The first study on the induction of in vitro rooting of Comanthera mucugensis was performed by Silva et al. (2005b), in which they tested different concentrations of sucrose $(5,10,15,20$ and 30 g. $\left.\mathrm{L}^{-1}\right)$ in MS $1 / 2$ medium for the formation of roots in plants germinated in vitro after 60 days of culture. They reported that after culture for 60 days, the concentration of 15 g. $\mathrm{L}^{-1}$ produced the 
best rooting results, with average of 5.96 roots per plantlet (Tab. 2) and $2.59 \mathrm{mg}$ of root dry matter. However, they did not evaluate the percentage of root formation or investigate the survival after the transfer of the plants to ex vitro condition. Furthermore, the induction of rooting was only tested in plantlets germinated in vitro, not in shoots from in vitro multiplication.

Lima-Brito et al. (2016) used MS 1/2 medium containing 15 g.L $\mathrm{L}^{-1}$ of sucrose, supplemented with $4.9 \mu \mathrm{M}$ indolebutyric acid - IBA to induce roots from shoots of Comanthera mucugensis generated by direct organogenesis. The authors evaluated the effect of different levels of photosynthetically active radiation (PAR) $\left(60,120\right.$ and $300 \mu \mathrm{mol} \mathrm{m}^{-2}$ $\mathrm{s}^{-1}$ ) and types of tube seals (PVC, cotton and plastic, enabling different aeration levels) on the in vitro rooting and observed a negative effect of increased aeration and light intensity on the growth of the microplants. The evaluations were also performed after 60 days of culture and the highest number of roots (14.55) was greater than that described by Silva et al. (2005b) (5.96). Furthermore, LimaBrito et al. (2016) evaluated the length of the longest root and rooting percentage (between 94.39 and $98.00 \%$ ) (Tab. 2). The microplants were later transferred to the ex vitro environment. Despite the progress achieved by Lima-Brito et al. (2016) in this micropropagation step, new studies should be conducted to try to find ways to reduce the time of in vitro growth and diminish the costs, given the high cost of the auxin used.

The application of auxin was also tested with C. curralensis by Albuquerque (2013), using different auxin types, AIB, NAA and indole acetic acid (IAA), at distinct concentrations $(0.00,0.22$, $0.44,0.88$ and $1.76 \mu \mathrm{M})$ to induce in vitro rooting.
The results indicated that the use of auxin was not effective in this step, with a rooting rate of $4.67 \%$ and averages of 3.65 and $0.48(\mathrm{~cm})$ for number and length of roots, respectively. Besides these low values, the author did not evaluate the rooting of shoots from in vitro multiplication.

\section{Acclimatization}

Lima-Brito et al. (2016) also acclimatized the C. mucugensis microplants by transferring them to pots containing substrate composed of soil + sand + vermiculite (1:1:1). The microplants were covered by the upper halves of PET bottles (uncapped after 15 days and removed after 30 days), maintained in a nursery under sombrite shading (70\%) and watered daily. In this step, they tested the influence of different types of tube seal (PVC, plastic and cotton) and level of photosynthetically active radiation (PAR) (60 and $120 \mu \mathrm{mol} \mathrm{m}^{-2} \mathrm{~s}^{-1}$ ) during the in vitro pre-acclimatization step on the plant ex vitro survival. This evaluation was carried out 90 days after transference to ex vitro conditions and the results indicated that $60 \mu \mathrm{mol} \mathrm{m} \mathrm{m}^{-2} \mathrm{~s}^{-1}$ of PAR associated with PVC or plastic seal induced the best survival rates, 76.12 and $73.28 \%$, respectively (Tab. 3). New studies should be conducted in order to increase plants' survival.

Another strategy was employed by Pereira et al. (2017) for acclimatization of microplants, analyzing the effect of inoculation of arbuscular mycorrhizal fungi (AMF) on the ex vitro plant survival. Native AMF, filtrate from the soil microbiota and AMF + soil filtrate were used, after 3 months $100 \%$ of the plants with AMF survived (Tab. 3), and after 11 months, the plants began to flower. At the end of the experiment, of the total of 8 plants/treatment, 5 survived with the

Table 2 - Studies on in vitro rooting of sempre-vivas species.

\begin{tabular}{lccccc}
\hline Reference & Treatment with best result & $\begin{array}{c}\text { Percentage } \\
\text { of responsive } \\
\text { explants }\end{array}$ & $\begin{array}{c}\text { Number } \\
\text { of roots }\end{array}$ & $\begin{array}{c}\text { Length of longest } \\
\text { root (mm) }\end{array}$ & Species \\
\hline Silva et al. $(2005 \mathrm{~b})$ & $15 \mathrm{~g} . \mathrm{L}^{-1}$ of sucrose & Not evaluated & 5.96 & Not evaluated & $\begin{array}{c}\text { Comanthera } \\
\text { mucugensis }\end{array}$ \\
Lima-Brito et al. $(2016)$ & $4.9 \mu \mathrm{M}$ of IBA & 97.80 & 14.55 & 15.6 & $\begin{array}{c}\text { Comanthera } \\
\text { mucugensis }\end{array}$ \\
Albuquerque (2013) & No regulator & 4,67 & 3,65 & 0,48 & $\begin{array}{c}\text { Comanthera } \\
\text { curralensis }\end{array}$ \\
\hline
\end{tabular}


Table 3 - Studies on acclimatization of sempre-vivas species.

\begin{tabular}{|c|c|c|c|}
\hline Authors & Survival (\%) & Treatment with best result & Species \\
\hline Lima-Brito et al. (2016) & 76.12 & Soil + sand + vermiculite + SRWL $*$ & Comanthera mucugensis \\
\hline Pereira et al. (2017) & 100 & $\mathrm{AMF}^{* *}$ & Comanthera mucugensis \\
\hline Pêgo et al. (2013) & 74 & Sand + SRWL & Comanthera elegantula \\
\hline Pêgo et al. (2014) & 25.6 & Sand, vermiculite and Plantmax ${ }^{\mathrm{TM}}+\mathrm{SRWL}$ & Comanthera elegans \\
\hline
\end{tabular}

AMF treatment and 7 with the AMF + filtrate. The authors suggested further studies to assess the influence of the fungi alone.

Both studies demonstrated that it is possible to micropropagate $C$. mucugensis, but new acclimatization strategies still need to be studied in order to obtain a larger number of surviving plants and to establish the best fungus species for inoculation.

In the previously mentioned study with Comanthera elegantula, Pêgo et al. (2013) evaluated the influence of different substrate types (sand, vermiculite and Plantmax ${ }^{\mathrm{TM}}$ ) on the survival of acclimatized plants. After transfer to the substrate, the plants were covered by clear plastic bags, which were perforated weekly until their removal after 30 days. The authors concluded that sand produced the best results for the species, with an ex vitro survival rate of $74 \%$ (Tab. 3 ).

This same strategy was used by Pêgo et al. (2014) for acclimatization of Comanthera elegans, and there was no significant effect of the substrate types and pre-acclimatization on the survival rate of the plants, which was $25.6 \%$ (Tab. 3). Therefore, new studies should also be conducted with both $C$. elegans and C. elegantula seeking to develop more efficient acclimatization strategies to increase the survival of these species after transfer to the ex vitro environment.

In vitro conservation of sempre-viva species

The first study on the in vitro conservation of Comanthera mucugensis was carried out by Lima-Brito et al. (2011b), in which they tested the influence of different concentrations and combinations of osmotic agents (sucrose, mannitol and sorbitol) and temperature $\left(18\right.$ and $\left.25^{\circ} \mathrm{C}\right)$ on the minimum growth induction of shoots obtained by direct organogenesis. Plants' survival rate was evaluated after 180 days of culture and the authors concluded that the best treatment consisted of $15 \mathrm{~g}$ $\mathrm{L}^{-1}$ of sucrose at $18^{\circ} \mathrm{C}$, which induced survival of $97.5 \%$, thus recommending it for the medium-term conservation of this species (Tab. 4).

A different strategy was tested by LimaBrito et al. (2015) with Comanthera mucugensis, in which they applied different concentrations $(0.0,0.85,1.70,3.40$ and $6.80 \mu \mathrm{M})$ of the growth regulators ancymidol or paclobutrazol to reduce the growth, also with shoots obtained by direct organogenesis. The authors evaluated plants' survival after the same period (180 days) as LimaBrito et al. (2011b), and concluded that the culture medium without any growth regulator was more efficient, inducing a survival rate $81.25 \%$ (Tab. 4).

Both studies investigated in vitro conservation for only 180 days, and the authors used shoots formed by direct organogenesis. Therefore, further research is necessary to determine survival rates after longer periods of in vitro cultivation as well as using plants derived from in vitro germination, to allow the maintenance of the genetic variability of the species in in vitro collections.

The slow growth method was also applied by Albuquerque (2013) for in vitro conservation of the sempre-viva species $C$. curralensis. The author tested different osmotic agents, combining concentrations of sucrose $\left(15,30\right.$ or 45 g.L $\left.\mathrm{L}^{-1}\right)$ with mannitol or sorbitol ( 0 or 23 g. $\left.\mathrm{L}^{-1}\right)$, and concluded that the use of 30 g. $\mathrm{L}^{-1}$ sucrose induced the highest survival rate, $24.8 \%$. Furthermore, the application of ancymidol and paclobutrazol was also evaluated, at different concentrations $(0.00,0.42,0.85,1.70$ and $3.40 \mu \mathrm{M})$. The highest survival rate $(63.25 \%)$ was obtained with $0.85 \mu \mathrm{M}$ ancymidol. In this study, the authors used plants derived from in vitro germination and the conservation period was only 180 days, so further research is necessary with longer time frames. 
Table 4 - Studies on in vitro conservation of sempre-vivas species through slow growth.

\begin{tabular}{lccccc}
\hline Authors & Treatment & Period & S\%* & Explant & Species \\
\hline Lima-Brito et al. (2011b) & MS $1 / 2+15 \mathrm{~g} . \mathrm{L}^{-1}$ sucrose at $18{ }^{\circ} \mathrm{C}$ & 180 days & 97.5 & Shoots & Comanthera mucugensis \\
Lima-Brito et al. (2015) & MS $1 / 2$ free ancymidol or paclobutrazol & 180 days & 81.25 & Shoots & Comanthera mucugensis \\
Albuquerque (2013) & $30 \mathrm{~g} . \mathrm{L}^{-1}$ sucrose & 180 days & 24.8 & Plant & Comanthera curralensis \\
& $0,85 \mu \mathrm{M}$ ancymidol & 180 days & 63.25 & Plant & Comanthera curralensis \\
\hline
\end{tabular}

* = Survival percentage.

\section{Conclusion}

Based on the results reported here, it is possible to infer that tissue culture is a viable alternative for propagation and conservation of the Comanthera genus. New studies should be carried out to optimize the protocols for production of seedlings/plantlets in commercial scale and for in vitro conservation in the medium range, as for Comathera mucugensis.

\section{Acknowledgment}

This study was financed in part by the Coordenação de Aperfeiçoamento de Pessoal de Nível Superior (CAPES), Brasil - Finance code 001.

\section{References}

Albuquerque MMS, Lima-Brito A, Lima APPS, Alvim BFM \& Santana JRFD (2016) In vitro establishment of Comanthera curralensis, "sempre viva" native of Chapada Diamantina - Bahia. Ciência Rural 46: 991-995.

Albuquerque MMS (2013) Micropropagação e conservação in vitro de "sempre vivas" nativas da Chapada Diamantina-BA. Dissertação de Mestrado. Universidade Estadual de Feira de Santana, Feira de Santana. 100p.

Arrigoni-Blank MF, Tavares FF, Blank AF, Santos MC, Menezes TSA \& Santana ADD (2014) In vitro conservation of Sweet Potato Genotypes. The Scientific World Journal 2014: 1-7.

CNCFlora (2012) Comanthera mucugensis, Comanthera elegans, Comanthera curralensis. In: Lista vermelha da flora brasileira. Versão 2012.2. Centro Nacional de Conservação da Flora. Available at <http:// cncflora.jbrj.gov.br/portal/pt-br/profile/Comanthera mucugensis $>$. Access on February 2019.

Coelho VAT, Dias GDMG, Rodas CL, Pasqual M, Ferreira MM \& Silva ML (2016) Potassium, calcium and magnesium in tropical ornamental plants micropropagation. Ornamental Horticulture 22: $74-80$.

Giulietti N, Giulietti AM, Pirani JR \& Menezes NL (1988) Estudos em sempre-vivas: importância econômica do extrativismo em Minas Gerais, Brasil. Acta Botanica Brasilica 1: 179-193.

Gurgel ZER (2017) Micropropagação e conservação de Comanthera mucugensis Giul. subsp. mucugensis. Tese de Doutorado. Universidade Estadual de Feira de Santana, Feira de Santana. 93p.

ICMBio - Instituto Chico Mendes de Conservação da Biodiversidade (2018) Serra do Espinhaço terá trilha de longo curso. Available at <http://www.icmbio. gov.br/portal/>. Access in February 2019.

Junghans TG \& Souza AS (2013) Aspectos práticos da micropropagação de plantas. $2^{\text {a }}$ ed. Embrapa, Brasilia. 385p.

Lima-Brito A, Resende SV, Lima COC, Alvim BM, Carneiro CE \& Santana JRF (2011a) In vitro morphogenesis of Syngonanthus mucugensis Giul: subsp. mucugensis. Ciência e Agrotecnologia 35: 502-510.

Lima-Brito A, Albuquerque MMS, Alvim BFM, Resende SV, Bellintani MC \& Santana JRF (2011b) Osmotic agents and temperature on in vitro conservation of sempre-viva. Ciência Rural 41: 1354-1361.

Lima-Brito A, Albuquerque MMS, Alvim BFM, Resende SV, Bellintani MC \& Santana JRF (2015) Plant growth regulators for in vitro minimal growth of Comanthera mucugensis. Plant Cell Culture \& Micropropagation 11: 11-18.

Lima-Brito A, Albuquerque MMS, Resende SV, Carneiro CE \& Santana JRF (2016) In vitro hardening in different enviroment and acclimatization of microplants of Comanthera mucugensis Giul. subsp. mucugensis Revista Ciência Agronômica 47: 152-161.

Lloyd G \& McCown B (1980) Commercially feasible micropropagation of mountain laurel, Kalmia latifolia, by use of shoot tip culture. Combined 
Proceedings International Plant Propagators Society 30: 421-327.

Moreira FC (2015) Cultivo e conservação in vitro de sempre vivas. Tese de Doutorado. Universidade Federal de Lavras, Lavras. 102p.

Murashige T \& Skoog FA (1962) Revised medium for rapid growth and bio assays with tobacco tissue cultures. Physiology Plantarum 15: 473-497.

Paixão-Santos J, Dornelles ALC, Silva JRS \& Rios AP (2003) Germinação in vitro de Syngonanthus mucugensis Giulietti. Sitientibus Série Ciências Biológicas 3: 120-124.

Paixão-Santos J, Dornelles ALC, Pereira FD \& Oliveira LM (2008) Callus induction in sempre-viva (Syngonanthus mucugensis Giulietti) using different types of explants and BAP concentrations. Acta Scientiarum - Biological Sciences 30: 127-131.

Paixão-Santos J, Dornelles ALC, Silva JRS, Santana JRF \& Lima-Brito A (2006) Ajuste do meio MS para o cultivo in vitro de Syngonanthus mucugensis Giulietti, espécie ameaçada de extinção. Sitientibus Série Ciências Biológicas 6: 36-39.

Pêgo RG, Paiva PDO \& Paiva R (2013) Micropropagation of Syngonanthus elegantulus. Ciência e Agrotecnologia 37: 32-39.
Pêgo RG, Paiva PDO \& Paiva R (2014) Micropropagation protocol for Syngonanthus elegans (Bong.) Ruhland: an ornamental species. Acta Scientiarum Agronomy 36: 347-353.

Pêgo RG, Paiva PDO \& Paiva R (2015) In vitro establishment of Syngonanthus paepalophyllus in different culture media. Acta Horticuturae 1083: 255-260.

Pereira LS, Santos IS, Alvim FC, Souza-Júnior JO \& Gross E (2017) Effect of arbuscular mycorrhizal fungi on survival and growth of micropropagated Comanthera mucugensis spp. mucugensis (Eriocaulaceae). African Journal of Agricultural Research 12: 1772-1780.

Silva JRS, Paixão-Santos J, Rios APS, Santana JRF \& Dorneles ALC (2005a) Estudo da germinação e morfologia do desenvolvimento pós-seminal de Syngonanthus mucugensis Giul. in vitro. Sitientibus, Série Ciências Biológicas 5: 60-62.

Silva JRS, Lima-Brito A, Santana JRF \& Dorneles ALC (2005b) Efeito da sacarose sobre o enraizamento e desenvolvimento in vitro de Syngonanthus mucugensis Giul. Sitientibus Série Ciências Biológicas 5: 56-59. 